\title{
ANALYSIS ON THE IMPOSITION OF ONLINE REKLAME TAX ACCORDING TO LAW NUMBER 28 OF 2009
}

\author{
Rizky Pratama Jawahir ${ }^{1}$, Catur Wido Haruni ${ }^{2}$, and Fitria Esfandiari ${ }^{3}$ \\ rzkypratamaj@gmail.com,widoharuni07@yahoo.com, fit.esfan@gmail.com \\ ${ }^{123}$ Universitas Muhammadiyah Malang \\ *Correspondence email: fit.esfan@gmail.com
}

\begin{abstract}
this research about the imposition of online reklame tax as reviewed from article 49 of law number 28 of 2009 concerning regional taxes and regional retribution. In the research discuss about tax imposition arrangements tax based advertisements online on the Internet and social media as well as the legal implications of not being regulated the basis for tax based advertisements online the internet and social media. Because there are differences in tax treatment between the implementation of conventional advertisements with the based advertisements online. Conventional advertisements are taxed in accordance with the Regional Tax and Retribution Law. However, unlike the case with the advertisement on the internet and social media. This research uses normative juridical research. The approach that is use are statute approach and conceptual approach. By using this approach can find online advertisements tax imposition arrangements tax based advertisements online on the Internet and social media as well as the legal implications of not being regulated the basis for tax based advertisements online the internet and social media. Based on this research of results, there are several provisions such as the Law on General Provisions and Tax Procedures, Act Income Tax and also the act of Value Added tax. However, conceptually, it is still unable to reach in detail the implementation of the tax based advertisements online. So that a legal vacuum, legal uncertainty in tax imposition and the gap in the value of justice in tax imposition. Based on this, it should be the Government strengthening the Laws and Regulations relating to Taxation. Then, collaborate with other government agencies in the field of communication and information technology. There is a need for a special provision that can accommodate the imposition of this online-based advertisement tax which is carried out through social media and the internet.
\end{abstract}

KEYWORDS: Taxation, Online Advertising and Tax Imposition

\section{INTRODUCTION}

The Indonesian state strengthens its identity by establishing and implementing the concept of a rule of law to regulate the state order, to maintain the stability of the government in protecting and protecting its citizens (Hidayah, Esfandiari, \& Al-Fatih, 2021). This is enshrined in Article 1 paragraph (3) of the Constitution of the Republic of Indonesia which reads (3) The State of Indonesia is a constitutional state (Kemenristekdikti, 2015).The existence of law is the dominant factor in regulating all aspects that exist in the environment of Indonesian citizens (Mahfud MD, 2015). The application of these provisions, we can find in every joint regulation regarding the activities of the state and citizens themselves (Anggraeni, 2014). This rule is embodied in a written law which later is binding and compels to comply with the applied rules (Sriniyati, 2020). For both activities carried 
out by citizens and the state itself, there is a rule that provides a legal basis for carrying out these activities (Ismayadie, 2019).

One of the arrangements for the existence of this provision is about taxes. In the other hand, taxes are one of the main sources of revenue for a country that is paid by the public as collection fees that can be imposed by the Government based on the provisions of tax laws and as an embodiment of public participation or taxpayers to directly and jointly carry out the necessary taxation obligations for state financing and national development(Dwi S Prasetyono, 2015). This is as stated in Article 1 Number 1 of Law Number 28 of 2007 concerning the Third Amendment to Law Number 6 of 1983 concerning General Provisions and Tax Procedures (UU KUP), which states that taxes are mandatory contributions to a state that is indebted by an individual or entity that is compelling under the law, without receiving direct compensation and used for the state's needs for the greatest prosperity of the people (Johan, Hikmah, \& Anditya, 2019). The existence of the KUP Law is based on economic, information technology, social and political developments. With this provision, to provide more justice, provide services to taxpayers, increase certainty and law enforcement and anticipate advances in information technology and changes in material provisions in the taxation sector (Suminarsasi \& Supriyadi, 2012). The KUP Law refers to the main policies arising from the situation experienced by the state (Mahfud MD, 2015).

The more information technology develops, the more laws that govern this information technology are also developing. So that it requires provisions made to regulate the course of the development of information technology. The use of information, media and communication technology has changed both the behavior of society and human civilization in various aspects, one of which is the use of electronic media or websites.(Dewi \& Firmansyah, 2019). Increasingly, website users continue to grow and there are more and more activities carried out through the media website because the website is easy to access and use (Suparni, 2009). As a result of this, there are now many activities using website media for marketing, one of which is the installation of billboards on websites and social media. By definition, the meaning of advertisement is a notification to the public about merchandise, with compliments or pictures and so on, to make the merchandise more salable(Indonesian Dictionary, 2016). In the applicable provisions, the meaning of billboards is regulated in Article 1 Number 27 of Law Number 28 of 2009 concerning Regional Taxes and Regional Retributions (PDRD Law), which states that advertisements are objects, tools, actions, or media whose forms and patterns are designed for commercial purposes to introduce, recommend, promote, or to attract general attention to goods, services, people, or bodies that can be seen, read, heard, felt, and/or enjoyed by the public. (Law no 28 of 2009).

If you look at the definition provided by the PDRD Law, it explains in detail the billboard itself. The definition given refers to a media that is used as a supporting factor to introduce or preach a good or service to attract public attention, and have a commercial or commercial character(Sabila, 2018). Both the definitions contained in the Indonesian Law Dictionary (KBBI) and the normative ones are almost the same. Both provide definitions that lead to a trade or commercial terms. This illustrates that in the installation of this billboard itself, there are taxes imposed because the direction of the advertisement itself is a supporting factor or a means of promoting goods or services to attract public attention and those traded are salable (Santoso, 2019). 
In practice, many forms of advertising are used to promote or introduce merchandise or service to the general public (Rosenblatt, 2011). Either through audiovisual to the form of images. Then, if you look at the types of billboards that are circulating, they also vary, both cloth billboards, air, stickers, films, and so on, which are regulated in the PDRD Law. Advertisements that are regulated in these provisions become objects of advertisement tax (Lutfhiyah, Saputri, \& Hati, 2020). This means, every form and type can be taxed under the applicable provisions (Putra \& Marsono, 2020).

Article 49 of the PDRD Law regulates the basis for the imposition of the Advertisement Tax itself. The basis for the tax on advertisements is the rental value for advertisements. If the advertisement is held by a third party, the rental value for the advertisement is based on the value of the advertisement contract. However, if the advertisement is organized independently, the rental value of the advertisement is calculated based on the type, materials used, location of placement, duration of operation, number, and size of the advertisement media. If the advertisement is organized by a third party, but that party does not have a bill of contact, then the NSR is determined by using the same factors as the advertisement that is held independently (Law No 28 of 2009). As for Article 49 of the PDRD Law as follows:

(1) The basis for the imposition of Advertising Tax is the Rental Value of Advertisements.

(2) If the Advertisement is held by a third party, the Rental Value of the Advertisement as referred to in paragraph (1) shall be determined based on the value of the Advertising Contract.

(3) If the Advertisement is held alone, the Value of the Rental of the Advertisement as referred to in paragraph (1) is calculated by taking into account the factors of type, materials used, location of placement, time, duration of operation, number and size of the advertisement media.

(4) In the event the Advertising Rental Value as referred to in paragraph (2) is unknown and/or deemed unreasonable, the Advertising Rental Value is determined using the factors referred to in paragraph (3).

(5) The method of calculating the Advertising Rental Value as referred to in paragraph (3) shall be stipulated by a Regional Regulation.

(6) The results of the calculation of the Rental Value of Advertisements as referred to in paragraph (5) shall be stipulated in a Regional Head Regulation.

In terms of the development of information technology, with the ease in using website media, social media, and others that are technology-based. So that there are also many billboards installed on the media platform. Billboards can now be found online (websites, applications, and other social media). This makes marketing carried out by private persons or business entities easy to attract public attention (Viana, Margareth, \& Serly, 2018). Especially in these conditions, the majority of people have been able to access websites in their daily lives (Hayaty \& Meylasari, 2018).

However, when viewed from the existing legal arrangements in Indonesia, the PDRD Law does not regulate these online-based billboards (Santoso, 2019). This means that the PDRD Law regulates more conventional advertising. So that the advertisement tax in onlinebased media is not taxed by the PDRD Law. So, article 49 of the PDRD Law which regulates the rental value of advertisements only applies to conventional billboards. 
Bodies of people who put up billboards in online-based media have made a lot of profit as a result of this installation. This should be part of the tax object and can be taxed. When viewed from Law Number 36 of 2008 concerning the Fourth Amendment to Law Number 7 of 1983 concerning Income Tax (UU PPH), this online-based advertisement may be taxed. Because based on Article 23 Paragraph (1) Letter C Number 2 which reads:

(1) The income mentioned below in whatever name and form is paid, provided to be paid, or payment has been due by a government agency, domestic corporate tax subject, activity organizer, permanent establishment, or foreign company representative. other taxpayers in the country or permanent establishment, withholding tax by the party that is obliged to pay:

c. $2 \%$ (two percent) of the gross amount of:

2. Fees in connection with technical services, management services, construction services, consulting services, and other services other than services that have been deducted by Income Tax as referred to in Article 21.

Through these provisions, classifying related to other services with a $2 \%$ tax deduction in the Regulation of the Minister of Finance of the Republic of Indonesia Number 141 / Pmk.03 / 2015 concerning Other Types of Services As Mentioned in Article 23 Paragraph (1) Letter C Number 2 of Law Number 7 of 1983 Concerning Income Tax, as Amended Several Times, and Lastly with Law Number 36 of 2008. In this regulation, the implementation of online-based billboards can be taxed if the business actor is an agent or intermediary in making online advertising transactions on social media. and website. In Article 4 Paragraph (1) of the PPH Law, it states that "The object of the tax is income, namely any additional economic capacity received or obtained by the Taxpayer, whether originating from Indonesia or from outside Indonesia, which can be used for consumption or to increase the assets of the Taxpayer concerned, under whatever name and form ".( Law 36 of 2008) So it is clear, with this provision, online-based advertisements should be taxed (Putra \& Marsono, 2020). This means that any additional life necessities received or obtained by each person or entity itself, which is used for consumption or to increase the wealth of the person or entity may be taxed on the business or activity or benefits obtained either from Indonesia or from outside Indonesia. Even in whatever form it has its useful value in an economic aspect.

Likewise in Law Number 42 of 2009 concerning the Third Amendment to Law Number 8 of 1983 concerning Value Added Tax on Goods and Services and Sales Tax on Luxury Goods (VAT Law). Due to the implementation of online-based billboards, it can be done by utilizing services, it can be said that services are taxable as regulated in Article 3A Paragraph (3) of the VAT Law, which reads that:

(3)Individuals or entities that utilize Intangible Taxable Goods from outside the Customs Area as referred to in Article 4 paragraph (1) letter d and/or who utilize Taxable Services from outside the Customs Area as referred to in Article 4 paragraph (1) letter e is obliged to collect, deposit and report the value-added tax payable, the calculation and procedure of which is regulated by a Regulation of the Minister of Finance.

So far, with the provisions in the VAT Law, $10 \%$ withholding tax can still be imposed. However, the installation of online-based billboards itself needs to be studied more deeply. The absence of laws or provisions governing the imposition of taxes on the installation of 
online-based advertisements indicates that there is a legal vacuum. Syukri Albani argues related to the legal vacuum, explaining that:

The legal vacuum can be interpreted as "a state of emptiness or absence of statutory regulations (laws that regulate (certain) order in society," so that the legal vacuum in positive law is more accurately described as "statutory void or statutory regulation." (Nasution, 2016)

This means that it is necessary to carry out an in-depth study to find out the tax imposed by the state on the perpetrators of the installation of this online billboard. This is for the author important enough to be considered in-depth because the current law in Indonesia is inseparable from legal positivism (written law) in which the theory leads to legal certainty for an action or activity carried out. So it is worth examining what kind of arrangements are provided by the State in supervising and imposing taxes on the installation of these online billboards.

Based on the description of the background explanation above. Therefore, the author wants to examine the basis of taxation for the installation of these online billboards and the legal implications for the nonregulation of taxation on the installation of these online billboards. Of the several problems that have existed in the background, the author tries to formulate several problems related to the background with the title as follows, How are the regulations for the imposition of online advertisement tax on websites and social media and What are the legal implications of not regulating the basis for taxation of online-based advertisements on websites and social media.

\section{RESEARCH METHODS}

The research method used in this research is the normative juridical research method. According to Peter Mahmud, "legal research is a process to find legal rules, legal principles and legal doctrines to answer legal problems that arise, with the result that can be achieved is to provide a prescription of what should be."(Marzkui, 2011). The legal research method is a way of working scientists who disrespect use the method. In the online dictionary, a method is defined as a way that an investigation or research must be examined based on a certain plan.(Ibrahim, 2006)

The author uses a statutory approach and a conceptual approach to analyze this research. The use of a statutory approach in this study aims to study the basis for the imposition of taxes on the installation of online-based billboards on websites and social media that are not regulated in any applicable provisions. This approach is used to analyze Article 49 of the PDRD Law.

The conceptual approach is used to analyze the framework or conceptual framework that is in line with this research. So of course it is necessary to put forward theories and concepts related to online advertising, tax bases, and other theories relevant to the imposition of online billboards tax. 


\section{RESULT AND DISCUSSION}

\section{A. Arrangements for the imposition of online-based advertisement tax through the website and social media}

In this study, the author tries to explain some positive national laws regarding the tax aspects of online-based advertisements that are carried out on social media and websites. Then analyzing related to some of these positive laws can be used to tax online-based advertisements which are carried out on social media and websites to meet the needs of the community. Because so far there is still a legal vacuum regarding the regulation of the imposition of advertisement taxes carried out on social media and websites as a form of development from conventional billboard rental services which are currently being carried out online which resulted in the abandonment of conventional billboards.

\section{a. Law Number 28 the Year 2007 Concerning the Third Amendment to Law Number 6 the Year 1983 Concerning General Provisions and Tax Procedures}

The installation of billboards through online media is mostly done through the social networks Facebook, Twitter, websites, and other social media. The connection with the installation of billboards through the website remains a tax object. Advertisement tax is a tax on the implementation of advertisements.( Undang-Undang Nomor 28 Tahun 2009) The advertisement tax does not apply to all regencies or cities in Indonesia. This is related to the authority given to district or city governments to impose or not to impose a type of district or city tax.

In connection with the problem, in this case, the installation of billboards through websites and social media, then as a person or entity that installs billboards through websites and other social media is a taxpayer because they get profit or income from an act or activity they do. So that these activities should be permanent and must be taxed and must submit a Tax Return as regulated in Article 6 of Law Number 28 of 2007 concerning General Tax Provisions (UU KUP). On a deeper look, the service providers or users of online-based advertisement services are none other than entrepreneurs, who by definition are regulated in Article 1 point 4 of the KUP Law which states that: "Entrepreneurs are private persons or entities in any form which in their business activities or jobs produce goods, import goods, export goods, carry out trading businesses, utilize intangible goods from outside the customs area, carry out service businesses, or utilize services from outside the customs area. In this case, online advertisement service providers do service businesses. So that in this case, this online advertisement service provider can also be said to be a Taxable Entrepreneur, which is defined in Article 1 Number 5 of the KUP Law that: "Taxable Entrepreneurs are Entrepreneurs who deliver Subjectable Goods. Tax and/or delivery of Taxable Services which is subject to tax under the Value Added Tax Law 1984 and its amendments. " In Article 4 of Law Number 42 of 2009 concerning the Third Amendment to Law Number 8 of 1983 concerning Value Added Goods and Services and Sales Tax on Luxury Goods (PPN Law), it states that value-added tax is imposed on several wrong points. one of which is the delivery of taxable services within the customs area carried out by Entrepreneurs and the use of taxable services from outside the customs area within the customs area.

According to the PPN Law, the meaning of services is any service activity based on an engagement or legal action that causes goods, facilities, facilities, or rights to be available for use, including services performed to produce goods due to orders or requests with materials 
and on the instructions of the buyer.( Law No 42 of 2009) Meanwhile, the meaning of taxable services is services that are subject to tax based on this law.

When viewed from the meaning of services in the VAT Law, the activities of organizing advertisements on social media and websites can be taxed which refers to value-added tax. Because the activities of organizing billboards on social media and websites include service activities, namely providing services for the installation of billboards. Also, some words are based on an agreement or legal action in which the provider and user of the advertisement service have agreed to carry out the legal action, namely in this case the user pays the rate requested by the provider and then the provider installs the billboard.

Reviewed based on article 4 letter c of the VAT Law, it is imposed on the delivery of taxable services within the customs area carried out by Entrepreneurs. To determine whether taxable service delivery is taxable, the following conditions must be met :

a) The requirements mentioned in Article 4 letter c

1. The services rendered are taxable

2. The delivery is made in the Indonesian customs area

3. Delivery is made in the framework of business activity or work.

b) Terms implicit in the VAT Law

Taxable Entrepreneurs, Entrepreneurs carrying out the activities of delivering Taxable Services include: either entrepreneurs who have been confirmed as Taxable Entrepreneurs or entrepreneurs who should have been confirmed as Taxable Entrepreneurs, but have not been confirmed. Also included in the definition of delivery of Taxable Services are Taxable Services which are utilized for their interests and/or which are provided free of charge. Article 4A Paragraph (3) of the PPN Law states that the types of services that are not subject to valueadded tax are certain services in the following service groups, one of which is broadcasting services that are not advertisement in nature. When using the interpretation based on the word law, it is clear that advertisements on the website, Facebook, Instagram, Twitter, and other social media are not included in those mentioned articles because they are advertisements for promotional purposes. Thus, an advertising service is a taxable service. There is an opinion that explains this tax collection, Kunarjo argues that "Tax collection is the activity of taking taxes as an obligation of the taxpayer on the use of certain facilities, services/services, or fields of work used by a person for their interest. Both in the form of goods or services which are subject to tax per applicable regulations. "(Kunarjo, 2004)

From the explanation above, it can be concluded that if the service is not carried out by a government agency, it can be taxed or in this case Value Added Tax, if it meets the applicable provisions, of course, online advertisement service providers on social media are not something to do. by individuals or a community that has access to social media or websites. For example, the commission (fee) received by the agent / service provider if it meets the requirements as stated in Article 4 letter $\mathrm{c}$ and the service performed by the agent, does not include exempt services as regulated in Article 4 A Paragraph (3) of the VAT Law. Article 4A Paragraph (3) of the PPN Law is then regulated in Article 3 Paragraph (1) Regulation of the Minister of Finance Number 40 / PMK.03 / 2010 concerning Procedures for Calculating, Collecting, Depositing, and Reporting Value Added Tax on Utilization of Intangible Taxable Goods and / Or Taxable Services from Outside the Customs Area, in which case the taxable services are deducted by $10 \%$ (ten percent), and multiplied according to what is paid (if the 
payment is not deducted by Value Added Tax). Then also explained, a deduction of 10/110 if the payment includes a discount for value added tax. Article 3 Paragraph (1) reads as follows:

(1) Value Added Tax payable on the utilization of intangible Taxable Goods and/or Taxable Services from outside the Customs Area is calculated in the following manner:

a. $10 \%$ (ten percent) multiplied by the amount paid or should have been paid to the party delivering intangible taxable goods and/or taxable services if the amount paid or should have been paid does not include Value Added Tax; or

b. 10/110 (ten per hundred and ten) multiplied by the amount paid or should have been paid to the party delivering intangible taxable goods and/or taxable services if the amount paid or should have been paid include Value Added Tax.

So far, advertising services on social media and websites are still possible to be subject to value-added tax on taxable services. Then in the KUP Law, business actors who provide services related to the implementation of advertisements on social media and this website have fulfilled the taxpayer elements in the KUP Law. So that the business actor or service provider is obliged to submit a Tax Return or SPT to report the income received.

\section{b. Law Number 32 of 2008 concerning the Fourth Amendment to Law Number 7 of 1983 concerning Income Tax}

In the taxation system, there are terms of direct tax and indirect tax. Direct tax is a tax that must be borne or borne by the taxpayer alone and cannot be delegated or imposed on other people or other parties. Meanwhile, indirect taxes are taxes that can ultimately be paid or delegated to other people. In income tax, use direct tax in the collection. According to Mansury, who stated that "Economically, a direct tax is a tax that is paid directly by the payer, where the tax burden cannot be transferred to other people or other parties. Included in this category is the income tax. Direct tax is progressive because this part of the taxable income will increase if the income is added to it. Law 32 of 2008 concerning the Fourth Amendment to Law Number 7 of 1983 concerning Income Tax (PPH Law) adopts the concept of separation between subjective obligations and objective obligations "(Mansury 2000).

With this separation, the terminology of the taxpayer other than the tax subject appears. According to Rachmad Soemitro, what is meant by a taxpayer is a person or entity that simultaneously meets subjective and objective requirements(Soemitro, 1992). Thus, a person or entity that has met the subjective requirements is not necessarily a Taxpayer, the person or entity must meet the objective requirements to become a Taxpayer, namely receiving or obtaining income which is the object of the tax. Of all the income tax categories in the PPH Law, namely income tax (Pph) Article 21, Pph Article 22, Pph Article 23, Pph Article 24, and Pph Article 25. Income tax Article 23 on advertising services in print media is what can is said to be almost fulfilling as the basis for the imposition of income tax generated by the activities of organizing online-based advertisements on social media and websites.

In the other hand, because Pph Article 23 Paragraph (1) letter c number 2 is a tax withheld on income derived from compensation in connection with technical services, management services, construction services, consulting services, and other services other than services that have been deducted by Income Tax as referred to in Article 21. It can be said that this onlin ebased advertising activity, including in the delivery of services that are exchanged for advertisement installation services carried out on social media or websites. 
Pph Article 23 is then further regulated in the Minister of Finance Regulation Number 141 / Pmk.03 / 2015 Regarding Other Types of Services As Mentioned in Article 23 Paragraph (1) Letter C Number 2 Law Number 7 the Year 1983 Concerning Income Taxes As Has Been Several Last Amended Times with Law Number 36 the Year 2008. This PMK provides further explanation of other services referred to in Article 23 Paragraph (1) letter c number 2. So that online-based advertising services can be categorized as intermediary services or services. creation of advertising promotion tools. In this provision later, there is a deduction of the income received, a deduction of $2 \%$ (two percent).

Based on Article 4 paragraph (1) of the PPH Law, it is clear that the object of income tax is any additional economic capacity. The meaning of this paragraph can also be interpreted that income from advertisement service transactions carried out on social media can be subject to income tax. By the opinion expressed by Mardiasmo who said that:

"Tax collection is an activity or activity to collect taxes that must be paid by taxpayers by officers or institutions that have the authority to collect taxes, as payment for the use of facilities or services provided to them. The payment is mandatory because the payer has utilized the facilities or services of another person. "(Mardiasmo, 2002)

However, to determine this, of course, first look at the tax payable arising from the transaction, because the most important thing in tax imposition is the presence of tax payable. In this regard, Rachmat Soemitro explained the tax debt, explaining that:

"Tax debt is a debt that is particularly important because the state (the creditor) is bound and cannot freely choose who will be the debtor, as in civil law. This happens considering that the tax debt was born because of the law. "(Soemitro, 1992)

The income of online advertisement service providers can already be subject to income tax based on existing regulations, but the supervision is not maximal. It is necessary to regulate the imposition of advertisement tax which is carried out on the internet and social media which is separate from the income tax itself, by using a self-assessment system, which is to give the taxpayer the confidence itself to calculate the tax owed. Self Assessment System has advantages and disadvantages, of course, taxpayers who must be active in reporting their taxes by taking care of themselves even though now it has been facilitated by the existence of e-filling in tax reporting. However, in addition to the freedom given, it can allow taxpayers to evade so that separate rules are needed for the installation of billboards on social media and websites which are expected to provide more supervision in fulfilling taxes for state treasury revenues.

\section{c. Law Number 28 of $\mathbf{2 0 0 9}$ concerning Regional Taxes and Regional Retributions}

When installing conventional advertisements, they must be taxed or pay taxes, while the perpetrators of installing online-based advertisements can be free from paying taxes, because equality and justice are one of the principles underlying taxation. The idea that supports the tax for the online-based advertisement installation activity is to achieve overall economic stability. The ease of doing business on the website and also the advantage of not having taxes will affect business behavior, more and more people or companies will switch from conventional trading methods to online-based trading to avoid taxes.

In article 1 number 27 of the PDRD Law, it states that the definition of billboards itself is as follows :

"Advertisements are objects, tools, actions, or media whose forms and patterns are designed for commercial purposes to introduce, recommend, promote, or to attract general attention to goods, services, people, or bodies, which can be seen, read, heard, felt. , and/or enjoyed by the 
public. "( Law No 28 of 2009). When examined definitively, online-based billboards also have similarities to the definition given in Article 1 Number 27 of the PDRD Law. This online-based advertisement also has the purpose of trading in goods and services. Then, has the value to introduce, recommend, promote, or attract public attention to goods, services, people, or bodies, which can be seen, read, heard, felt, and/or enjoyed by the public. So that this onlinebased billboard fulfills the definitive elements contained in the PDRD Law.

Advertising is either a person or entity that organizes advertisements both for and on behalf of itself or for and on behalf of other dependent parties. When you see these online billboards on websites and social media, several companies and individuals carry out advertising activities on these media.

Based on this, it can be concluded that in the Advertising Tax, the tax subject is an individual or entity using advertisements. Meanwhile, taxpayers are individuals or entities that organize billboards. Advertisements are held directly by private persons or entities that use advertisements for their interests, the advertisement taxpayers are such individuals or entities. If the advertising is carried out through a third party, for example, a billboard installation service company, the third party becomes the advertisement taxpayer. In the taxation system, in carrying out its tax obligations, taxpayers can be represented by certain parties permitted by local laws and regulations regarding advertisement tax. Taxpayer representatives are personally and or jointly responsible for the payment of taxes owed. Other than that, taxpayers can appoint a proxy with a special power of attorney to exercise their rights and fulfill their tax obligations.

However, the PDRD Law excludes the implementation of billboards through websites which should be an additional tax that is not only done conventionally but also online through websites and social media. Several reasons for the consideration of why the government needs to improve or add to these rules to include taxation of advertisements carried out on websites and social media which occur in a short time so that their development also occurs very quickly and makes it difficult for the government to trace who is the perpetrator of the transaction. In the advertisements carried out on websites and social media, anyone can be found and anything that could potentially be taxed.

When analyzed further, in general, conventional billboards that have existed so far on radio, television, and print media such as newspapers, do not have a significant difference compared to billboards on websites or social media. This means that the two have more in common and there are only a few differences.

There is no significant difference between the two billboard installation services that have been used so far, but only conventional billboards are subject to tax. This cannot be allowed to just happen because online-based billboards are more profitable, so many have switched to online-based billboards, causing losses to billboard agencies.

Actors of advertisements on social media or websites include owners of social media accounts or can be said to be advertisement organizers. The social media account is the place to promote which is a social media account such as Twitter or Instagram and the advertiser pays the owner of the account. The possibility of taxing social media accounts used to promote can be described as wanting to put up an advertisement, then having to pay taxes, determining when to install it until what date it is posted up to the size of the billboard. There is no difference if you want to put up billboards on social media, that is, those who want to put up a billboard contact the service provider (the account owner) then if it matches the price set by 
the service provider, he sends the goods to the service provider which will be promoted while paying for the installation of the bill the service will post the desired billboard. The payment made is adjusted to the billboard rental value as regulated in Article 49 of the PDRD Law.

Due to the calculation of the advertisement tax that must be adjusted to the value of the advertisement rental, so calculating the tax collection must pay attention to the factors that exist in the PDRD Law and be associated with the rental value of the advertisement. Then, in Article 49 of the PDRD Law, the advertisement tax imposition is based on the advertisement rental value itself. Calculated by taking into account the factors of type, materials used, location of placement, time of day, duration of operation, number, and size of advertisement media. The implementation of online-based billboards is the same as conventional billboards when viewed from the way it works.

So it is very possible if advertisements on social media or websites are subject to advertisement tax as is the conventional advertisement tax imposed in the PDRD Law. Although the online-based advertisement tax can be imposed, it is not suitable if it is included in the advertisement tax because the advertisement tax is a regional tax, while the online-based advertisement installation activity cannot be determined in certain areas but throughout the territory of the Unitary Republic of Indonesia (NKRI). So of course, this law cannot yet be used as a juridical basis for the imposition of an online advertisement tax through social media.

Based on the foregoing, the tax potential of online-based advertisements on websites and social media is very possible to be taxed based on deeds, circumstances, or events concerning formal views. When viewed from the principle of equality (equality) where tax imposition must be by the ability of the taxpayer. In line with this, Y. Sri Pudyatmoko stated that:

"The principle of equality is a derivative of the principle of equity, which is one of the principles in tax collection. The principle of equity was first expressed by Adam Smith, wherein the context of material tax law, this principle emphasizes the existence of a balanced distribution of tax pressure among tax subjects according to their ability (ability to pay) and in balance with the income they earn. "(Pudyatmoko, 2006)

So based on this principle, the imposition of advertisement tax for the implementation of advertisements on websites and social media can be said to be fair enough so that all billboards both conventionally and on websites and social media are not tax-free. Likewise, with the income obtained from the existence of advertisements on websites and social media, it can be said that it is sufficient for tax payments. Then, the advertisement tax collection is only reported if there is an activity or there is a form of advertising.

\section{B. Legal Implications of Unregulated Basis for Imposing Online-Based Advertising} Tax on Websites and Social Media

\section{a. There is a legal vacuum against the imposition of online advertisement tax}

The legal vacuum that is often encountered in practice, is an event or problem that occurs in a society that has not been regulated in law or legislation, or even though it is regulated but is incomplete and unclear. Therefore, these unclear legal regulations must be explained, those that are incomplete must be completed and those that do not have any regulations must be established using legal discovery. In connection with the implementation of this online-based advertisement, no law regulates this. Meanwhile, the development of online-based billboards on websites and social media is growing progressively every day and of course, there is income for actors or service providers who carry out billboards on websites and social media. However, due to the absence of a clear legal arrangement, the imposition of taxes on the implementation of this online advertisement cannot be taxed. "A just and orderly 
national law can be a definite measure in society, but in reality, the existing law is still not able to accommodate and is far behind by the development of society. This is the cause of confusion (chaos) in society regarding what rules should be used or applied so that in society there is no certainty about the rules that are applied to regulate things or circumstances that occur. "(Mitendra, 2018)

By not regulating the implementation of online-based billboards through websites and social media, it will result in the absence of legal certainty in terms of tax imposition. The current tax laws in Indonesia are still not able to accommodate, activities or actions that have an income carried out by taxpayers on websites and social media. The development of technology and the development of society with the law should go hand in hand. Due to the law that must follow these developments. To be able to accommodate the needs of citizens in terms of taxation.

\section{b. Legal Uncertainty Against Online-Based Advertising Tax}

Especially in tax law which is a law that must be obeyed by citizens. By not regulating the tax imposition on online-based advertisement tax, because the tax imposition is related to the tax rate, thus there is no obligation for the State to impose taxes on the existence of this online-based advertising. There is an opinion expressed by Y. Sri Pudyatmoko that Tax imposition is based on a borne tax object, tax imposition talks about the tax rate itself. So namely the amount on which the tax is imposed or the amount subject to tax (tax base) and the rate applied to it (tax rates) (Pudyatmoko, 2008).

In terms of regulating online-based advertisement taxes on websites or social media, there are no clear and detailed regulations that can be used as a juridical basis for the government to impose taxes from the results of organizing these online-based advertisements. However, there are only a few positive laws that are still very minimal and not comprehensive if they are used as a juridical basis for the imposition of online-based advertisement tax on websites and social media. So that all provisions of the law must be clear and firm and do not provide opportunities for anyone to provide another interpretation of the will of the legislator.

\section{c. There is a gap in the value of justice in tax imposition}

In connection with the value of justice, which is the main substance in policy formulation. The principle of justice is very abstract and subjective, so it is very difficult to find a formula that can fulfill all aspects of justice. No policy can satisfy all parties, if on the one hand a policy is considered fair, but not necessarily fair from the other side. Justice is a tax imposed on an individual which should be proportional to the ability to pay taxes or the ability to pay and by the benefits received (Waluyo, 2011). This is because the tax collection system in Indonesia uses a self-assessment system, which is a tax collection system that gives taxpayers confidence to calculate, pay and report the amount of tax that should be owed based on tax laws and regulations. "(Suminarsasi \& Supriyadi, 2012). Fairness in legislation includes imposing taxes in general and evenly, and according to their respective abilities. Meanwhile, it is fair in its implementation, namely by giving taxpayers the right to file objections, delay in payment, and file an appeal. Because taxes are a balance between rights and obligations to both the state and its people. The state collects taxes as well as utilizes taxes for the welfare of the community. This welfare is provided by the state through facilities that support the improvement of the people's standard of living.(A \& Suryaputri, 2018)

While in practice, there is a form of advertisement that is by technological developments, namely online-based billboards. In the implementation of online-based billboards, there is no clear regulation on tax imposition. Meanwhile, the income earned is possibly be taxed. Meanwhile, the implementation of conventional advertisements is subject to tax by the PDRD Law itself. This shows that there is an imbalance in the legal arrangement in terms of taxation 
on advertisement operations. So that the value of justice that lives in society, becomes disturbed.

\section{CONCLUSION}

1. Arrangements for the imposition of online-based advertisement tax through social media and websites

a. Law Number 28 the Year 2007 Concerning the Third Amendment to Law Number 6 the Year 1983 Concerning General Provisions and Tax Procedures (UU KUP), this online-based advertisement may be taxed. This is because business actors can be categorized as service providers for the implementation of this online-based advertisement. Thus, the service provider fulfills the entrepreneurial element and the taxable entrepreneur element in this provision. Concerning the services provided, it also fulfills the elements of taxable services. So that on this basis, in this KUP Law, taxes on the implementation of online-based advertisements can be taxed. However, the weaknesses are still not detailed and are still general in regulating the existence of this online-based billboard.

b. Law Number 32 the Year 2008 Concerning the Fourth Amendment to Law Number 7 the Year 1983 Concerning Income Tax (PPh Law), one of the income taxes is contained in Article 23 Paragraph (1) letter c. This provision is related to rewards, because the rewards given to online-based advertisement service providers, it is subject to a tax deduction of $2 \%$ of the income received. Judging from the Income Tax Law it can be taxed. However, it is necessary to regulate the imposition of this online-based advertisement tax, using a self-assessment tax collection system.

c. Law Number 28 of 2009 concerning Regional Taxes and Regional Levies (PDRD Law), the regulated tax is a regional tax and is related to the advertisement tax imposed on the implementation of advertisements based on the value of the billboard rental. So that the calculations need to pay attention to the factors contained in this PDRD Law. However, to be taxed on the implementation of onlinebased advertisements on social media and websites is not suitable to be included in the advertisement tax which is a local tax. Meanwhile, online-based advertisements on social media and websites are not only carried out in the regions but throughout Indonesia.

2. Legal Implications of Unregulated Basis for Imposing Online-Based Advertising Taxes on Websites, Social Media, and Others

a. There is a legal vacuum on the regulation of tax imposition related to the implementation of online-based advertisements on social media and websites. So that in the collection of taxes it is still not clear to be able to be taxed. In fact, in the development of technology and information, many have installed these onlinebased billboards on social media and websites.

b. Legal uncertainty regarding the imposition of online-based advertisement tax, seen from several statutory provisions, there are several that can be taxed. However, if it is examined further, it is still not clear and detailed in imposing taxes. So it can be said, there is still no legal certainty in taxing the implementation of online-based advertisements through social media and websites.

c. There is a gap in the value of justice in tax imposition. The principle of fairness in tax imposition is the most important thing that needs attention. In the absence of clear 
and appropriate legal arrangements to impose taxes on the implementation of online-based advertisements through social media and websites. So that business people with this online-based advertisement service provider are free from taxation. Thus, the value of fairness in collecting or imposing taxes on an income is a gap in this case.

\section{b. Suggestion}

From the description of the research results and the discussion that has been included in the conclusion. There are several suggestions put forward by the author to solve legal problems in organizing online-based advertisements through social media and websites, including the following:

1. The government needs to strengthen existing laws and regulations, especially the rules regarding the imposition of online-based Advertising Tax, which can be included in the value-added tax category in Article 4 Paragraph (3) and income tax in Article 23 Paragraph (1) letter c figures 2. Because existing laws have not specifically regulated it is still possible for tax avoidance to occur by the perpetrators of organizing these online billboards.

2. The government should be able to cooperate with other government agencies such as the Ministry of Communication and Information of the Republic of Indonesia to maximize revenue and supervision of online advertisement taxes so that these business actors do not run away in collecting taxes on services performed on social media or online websites.

3. It is necessary to have a legal product that provides a clear and detailed regulation relating to the regulation of online-based advertisement tax through social media and websites. Given the legal system adopted in Indonesia, it tends to be positive law or written law. So that legal certainty can be accommodated in terms of tax imposition. By prioritizing the principles of tax collection.

\section{REFERENCCES}

. S., \& Sabila, N. (2018). Analisis Pelaksanaan Online System Pajak Daerah Dalam Rangka Penerimaan Pajak Hiburan dan Pajak Restoran pada Suku Badan Pajak dan Retribusi Daerah Kota Administrasi Jakart Pusat Tahun 2014- 2016. Jurnal STEI Ekonomi, 27(1). https://doi.org/10.36406/jemi.v27i1.157

A, A. R., \& Suryaputri, R. V. (2018). Pengaruh Keadilan Perpajakan, Sistem Perpajakan, Diskriminasi Perpajakan, Kepatuhan Wajib Pajak Terhadap Penggelapan Pajak. Jurnal Akuntansi Trisakti.

Anggraeni, T. D. (2014). MENCIPTAKAN SISTEM PELAYANAN PUBLIK YANG BAIK: STRATEGI REFORMASI BIROKRASI DALAM PEMBERANTASAN KORUPSI. Jurnal Rechts Vinding: Media Pembinaan Hukum Nasional. https://doi.org/10.33331/rechtsvinding.v3i3.34

Dewi, R. K., \& Firmansyah, R. (2019). Analisis Kepuasan Pengguna Website Pajak Online Kota Bandung Menggunakan Model Evaluasi Terintegrasi. Swabumi, 7(1). https://doi.org/10.31294/swabumi.v7i1.5569

Dwi S Prasetyono. (2015). Pengertian Pajak. Jurnal Universitas Terbuka 3.

Hayaty, M., \& Meylasari, D. (2018). Implementasi Website Berbasis Search Engine Optimization (SEO) Sebagai Media Promosi. Jurnal Informatika, 5(2). https://doi.org/10.31311/ji.v5i2.4027

Hidayah, N., Esfandiari, F., \& Al-Fatih, S. (2021). Indonesia's Inability in Removing Self 
from Colonial Law (Study of Employment Laws). https://doi.org/10.4108/eai.1-72020.2303650

Ibrahim, J. (2006). Teori dan Metodologi Penelitian Hukum Normatif.

Ismayadie, M. (2019). ANALISIS EFEKTIVITAS DAN KONTRIBUSI PENERIMAAN PAJAK BUMI DAN BANGUNAN (PBB) DAN PAJAK PENGHASILAN (PPH) TERHADAP PENDAPATAN NEGARA TAHUN 2007-2017. Equity: Jurnal Ekonomi, 7(2). https://doi.org/10.33019/equity.v7i2.5

Johan, A., Hikmah, F., \& Anditya, A. (2019). Perpajakan Optimal dalam Perspektif Hukum Pajak Berfalsafah Pancasila. Jurnal Magister Hukum Udayana (Udayana Master Law Journal), 8(3). https://doi.org/10.24843/jmhu.2019.v08.i03.p03

Kemenristekdikti. (2015). Undang-Undang Dasar Republik Indonesia 1945. Resntra Kemenristekdikti 2015-2019.

Kunarjo. (2004). Hukum Perpajakan Indonesia.

Lutfhiyah, U., Saputri, L. D., \& Hati, F. M. (2020). Efisiensi Pembayaran Pajak Berbasis Online Dalam Rangka Penerapan Program Smart City Di Kota Malang. ... Pemerintahan Di Era ....

Mardiasmo. (2002). Perpajakan.

Marzkui, P. M. (2011). Penelitian Hukum.

MD, M. M. (2015). ASPEK HUKUM NEGARA DAN ADMINISTRASI NEGARA KELEMBAGAAN PENGADILAN PAJAK. Jurnal Hukum Dan Peradilan. https://doi.org/10.25216/jhp.4.3.2015.351-360

Mitendra, H. M. (2018). Fenomena Dalam Kekosongan Hukum. Jurnal Rechtsvinding.

Nasution, M. S. A. (2016). Hukum Dalam Pendekatan Filsafat.

Pudyatmoko, Y. S. (2006). Hukum Pajak.

Pudyatmoko, Y. S. (2008). Pengantar Hukum Pajak.

Putra, A. A., \& Marsono, S. (2020). Pengaruh Penerapan Sistem Online Pajak (ERegistration, E-Filing, dan E-Billing) Terhadap Tingkat Kepatuhan Wajib Pajak Orang Pribadi. Jurnal Akuntansi, 7(1).

R, M. (2000). Pajak Penghasilan Lanjutan Pasca Reformasi.

Rosenblatt, A. J. (2011). Integrated Online and Offline Advocacy Campaign Strategy. In Electronic Government. https://doi.org/10.4018/978-1-59904-947-2.ch121

Santoso, D. (2019). Pengenaan Pajak Terhadap Perdagangan Online di Indonesia Setelah Dibatalkannya Peraturan Menteri Keuangan (PMK) Nomor 210/PMK.010/2018. Jurnal Panorama Hukum, 4(2). https://doi.org/10.21067/jph.v4i2.3920

Soemitro, R. (1992). Asas dan Dasar Perpajakan Edisi Revisi.

Sriniyati, S. (2020). Pengaruh Moral Pajak, Sanksi Pajak, dan Kebijakan Pengampunan Pajak Terhadap Kepatuhan Pajak Wajib Pajak Orang Pribadi. JURNAL AKUNTANSI, $\begin{array}{llll}\text { EKONOMI Dan MANAJEMEN BISNIS, } & 8(1) \text {. }\end{array}$ https://doi.org/10.30871/jaemb.v8i1.1913

Suminarsasi, W., \& Supriyadi. (2012). Pengaruh Keadilan, Sistem Perpajakan, dan Diskriminasi terhadap Persepsi Wajib Pajak Mengenai Etika Penggelapan Pajak (Tax Evasion). Multiparadigma Lecture2, 1(2), 0-29.

Suparni, N. (2009). Cyberspace Problematika dan Antisipasi Pengaturannya.

Viana, E. R., Margareth, P., \& Serly, -. (2018). Menelisik Pajak Penghasilan Atas Bisnis Online Shop. InFestasi, 13(2). https://doi.org/10.21107/infestasi.v13i2.3515 Waluyo. (2011). Perpajakan Indonesia. 